\title{
LINGUAGEM E CONHECIMENTO NO CRÁTILO DE PLATÃO
}

\author{
Maria Aparecida de Paiva Montenegro ${ }^{1}$ \\ mariamonte_7@hotmail.com
}

RESUMO Ao final do diálogo Crátilo de Platão, deparamo-nos com a constatação de que os nomes não seriam capazes de dizer a essência das coisas, o que parece pôr em xeque a tarefa da filosofia pensada como atividade de busca do conhecimento presidida pelo lógos. O presente artigo pretende mostrar que é possível entrever, a partir da própria construção dos elementos que compõem o diálogo, sobretudo em sua dimensão dramática, indicações de que a linguagem não é destituída de seu papel de viabilizar o conhecimento.

Palavras-chave Crátilo; Platão; Linguagem; Conhecimento.

ABSTRACT As we reach the end of Plato's dialogue Cratylus, we face the conclusion that names would fail to express the real essence of things, which seems to question the task of Philosophy conceived of as an activity in search of knowledge controlled by logos. The present paper attempts to show that it is possible to perceive, from the very construction of the elements that make up the dialogue itself, mainly with regard to its dramatic dimension, clues which suggest that language is not unable to play its part as knowledge maker.

Keywords Cratylus; Plato; Language; Knowledge. 
O Crátilo parece desconcertante a quem pretenda mostrar que é inextrincável a relação entre linguagem e conhecimento, uma vez que a argumentação levada a cabo conduz, ao final do diálogo, a um duplo encurralamento: de um lado, os nomes, pensados como imitações da realidade, guardariam significados ambíguos, de modo a poderem significar tanto a imagem de uma realidade que é puro fluxo quanto a de uma que é sempre a mesma (Crátilo 437c) - nesse caso, não haveria um critério legítimo capaz de orientar a demarcação da verdade e, conseqüentemente, comprometeria a possibilidade mesma do conhecimento; de outro, se os nomes imitam a realidade e são a condição de acesso ao conhecimento da mesma, como ter-se-iam estabelecido os primeiros nomes se aquele que assim os criou - o nomoteta - não dispunha de nome algum que pudesse dar-lhe a conhecer a realidade que passaria a nomear (Crátilo 438b)? Em resposta a essas aporias, Sócrates propõe que se procure "outras entidades, para além dos nomes, que nos mostrem, sem os nomes, qual dos dois grupos é o verdadeiro (a realidade como fluxo ou como permanência), exibindo de forma clara a verdade dos seres" (Crátilo 438d).

O problema que imediatamente decorre de tal suposição é que, em se tornando admissível a possibilidade de acesso às coisas mesmas sem o intermédio dos nomes, o conhecimento passa a ser pensado como processo que pode prescindir da linguagem (Crátilo 438e) e, por conseguinte, deixa de se constituir como uma atividade eminentemente presidida pelo lógos. Estaria Platão tentando apontar para o caráter místico do conhecimento? Ou, então, seria o Crátilo um diálogo incapaz de dar conta das questões que levanta? Nesse caso, deve o leitor recorrer a respostas mais satisfatórias em diálogos como o Sofista (260a), no qual ser e pensamento se tornam indissociáveis, além de ampliar a discussão do âmbito dos nomes para o do discurso (Sofista 262b)? E o que dizer da corajosa associação que Monique Dixsaut (2003) propõe entre o Crátilo e o Fédon, considerando que neste se encontra explicitada justamente o que parece faltar àquele, a saber, a suposta doutrina platônica das formas e uma teoria da alma?

A partir dessa relação proposta por Dixsaut (2003), nossa hipótese é que se pode depreender, do interior do próprio Crátilo, algumas pistas que nos permitem, pelo menos, entrever alguma solução para a aparente impossibilidade de acesso ao conhecimento pela linguagem. Se nos valemos do cotejo desses e de outros diálogos é apenas para reiterar o que ali já se acha de algum modo presente.

Ora, como é característico dos diálogos de Platão (Hösle, 2002), o Crátilo nos oferece, senão as respostas, ao menos, um tratamento condigno à sua questão 
central - qual seja, a justeza dos nomes (orthotês onomatôn) -, lá mesmo onde não esperamos encontrar: no seu contexto dramático, nas passagens aparentemente destituídas de importância. No que tange especificamente ao nosso diálogo, tem-se uma longa parte dedicada às etimologias que, até o presente, tem suscitado em seus comentadores especializados (Goldschmidt, 1982; Barney, 2001; Sedley, 2003) as mais diferentes interpretações. Uma vez que as etimologias ali contidas são praticamente forjadas por Platão, não correspondendo ao que é obtido pelo competente trabalho da filologia, para uns tratar-se-ia de uma oportunidade que o filósofo teria encontrado para fazer ironias cujo sentido, bem como seus respectivos destinatários, escapariam à nossa compreensão, dada a nossa distância do contexto em que o diálogo foi escrito. Outros, como Levin (2001), procuram aproximá-la de uma crítica à poesia, por meio da qual Platão tentaria refazer as etimologias sugeridas pelos poetas, em virtude de estas serem destituídas de um cunho propriamente filosófico. Sedley (2003), por seu turno, supõe que, se levadas a sério como realmente merecem, a seção dedicada às etimologias contém não somente a chave para a interpretação do diálogo, mas também de toda a concepção platônica de linguagem. Na esteira desta última, supomos que a longa parte dedicada às etimologias constituiria precisamente um lugar privilegiado, no qual Platão apresenta, de modo, por assim dizer, performático, uma espécie de ilustração daquilo mesmo que é abordado no decorrer do diálogo: a adequação dos nomes às coisas, subjacente a qual se pode entrever uma concepção de significação atrelada, por sua vez, a uma certa noção de "forma" e "alma". Faremos a seguir uma breve recapitulação do diálogo propriamente dito, antes de passarmos ao exame das questões que nos propomos investigar.

Em qualquer comentário sobre a obra em foco tem-se, mais ou menos, o seguinte resumo: o diálogo versa sobre a justeza dos nomes a partir do exame realizado por Sócrates das teses divergentes de Hermógenes e Crátilo, já exauridos por uma discussão que não chega a um acordo. Segundo Hermógenes, os nomes são resultantes de pura convenção, podendo esta ser tanto individual quanto coletiva; para Crátilo, discípulo de Heráclito e mestre de Platão anteriormente a Sócrates, os nomes espelham a natureza das coisas e esta não é senão o constante fluxo. Sócrates é chamado para tentar uma conciliação e termina por apontar para as aporias já mencionadas. Ao final, tudo se passa como se elas fossem a saída mais adequada ante o risco do relativismo contido na tese de Hermógenes - aproximada ao perspectivismo de Protágoras -, bem como frente ao ceticismo decorrente do fluxismo heraclítico defendido por Crátilo. Ou, ainda, tudo leva a crer que a tese supostamente ensejada por Platão e enunciada por Sócrates - a saber, que os nomes espelham a natureza 
das coisas, sendo esta natureza aquilo que permanece o mesmo e não o fluxo -, também não se mostraria plausível. Isto porque acabaria lançando mão de uma hipótese muito semelhante àquela que conduz igualmente o Teeteto a um final aporético (Annas, 2006). Trata-se da suposição segundo a qual seriam as letras e sílabas, ao invés dos nomes, que, por guardarem o sinal (typos) das essências, espelhariam a natureza das coisas. O problema, contudo, é que na condição de nomes primitivos ou proto-elementos, as letras e sílabas não teriam um significado apreensível e, conseqüentemente, não poderiam dar a conhecer o significado dos nomes derivados que eles próprios compõem. De um modo ou de outro, todas as teses convergiriam para o desmembramento da associação entre linguagem e conhecimento. Em outros termos, a linguagem não seria capaz de dizer as coisas, mais precisamente, a essência delas, de forma que o conhecimento seria viabilizado por um acesso às coisas mesmas, independentemente da linguagem. Nesse caso, a filosofia, em sua dimensão dialógica e pedagógica, tão amplamente ressaltada em todos os diálogos de Platão, ficaria totalmente inviabilizada, devendo ser pensada como uma atividade de natureza inenarrável, de cunho eminentemente privado.

E é exatamente para evitar a interpretação de que se trata aí de uma autocrítica platônica - que a nosso ver mais se assemelharia a uma autofagia - que alguns comentadores (Gaudin, 1996; Santos, 2001) recorrem a diálogos como o Sofista e o Fédon, mostrando que nestes aparece aquilo mesmo que acreditam faltar ao Crátilo: uma teoria da significação e uma teoria das formas vinculadas a uma teoria da alma imortal. Com isso, todavia, permanecem pouco exploradas as ilustrações da concepção platônica de significação associada a uma ontologia das formas e da alma - presentes na parte dedicada às etimologias. Acreditamos, portanto, que se prestarmos um pouco mais de atenção a essa seção supostamente etimológica - essa que é justamente a parte mais extensa do diálogo -, teríamos a oportunidade de acompanhar o modo como Platão parece supor que deva proceder o dialético - encarnado na figura de Sócrates -,acerca do melhor uso a se fazer dos nomes.

Com efeito, Sócrates demonstra uma magistral destreza e loquacidade ${ }^{2}$ ao apontar para a ambigüidade de significados contida nos nomes, a fim de sempre fazer emergir dos mesmos uma conotação de cunho filosófico. Contudo, essa conotação difere tanto do sentido supostamente herdado da tradição poética (Levin, 2001) quanto daquele cuja origem é atribuída aos filósofos da phýsis. Essa estratégia platônica de apresentar sua filosofia confere, a nosso ver, uma diálogo de Platão -, com quem Sócrates diz ter estado em companhia pouco antes (Crátilo 396d). 
dimensão pragmática à mesma, uma vez que o filósofo se vale, em grande parte de sua obra, do expediente de pôr em ato, no próprio plano dramático, aquilo mesmo que é o tema da discussão do diálogo. Ora, se Sedley (2003) tem razão ao supor que Platão escolheu escrever sua obra sob a forma de diálogos para torná-la mais condizente com seu próprio modo de pensar a filosofia, a saber, fazendo-a coincidir com a dialética, talvez pareça menos estranho atribuir-lhe uma dimensão pragmática do que aquela mais doutrinária, identificada por uma vasta geração de comentadores.

Lembremos que no Crátilo (390c) é justamente o dialético que é apontado como aquele que sabe como nenhum outro usar adequadamente os nomes, supostos como instrumentos (Crátilo 388a) fabricados por um legislador de nomes - nomoteta -, "o mais raro dos artistas que surgem entre os homens" (Crátilo 389a). Assim, enquanto o trabalho do nomoteta é o de fazer nomes, fixando os olhos na natureza do nome de cada coisa que é (Crátilo 390e), o dialético supervisiona esse trabalho (Crátilo 390d), a partir de sua atividade de fazer perguntas e dar respostas (Crátilo 390c). No passo 388b-c de nosso diálogo, aos nomes é atribuída a função de distinguir, separar (diakritikôs) e ensinar (didaskalilkôs) a essência das coisas, o que parece coincidir com a noção de dialética, tal como é definida no Sofista (253d): divisão por gêneros, de modo a não tomar por outra uma forma que é a mesma, nem pela mesma uma forma que é outra.

A seção dedicada às etimologias vem justamente ilustrar aquilo que, no plano interno do diálogo, Sócrates acaba de obter de Hermógenes: 1) a renúncia ao convencionalismo em prol da tese segundo a qual os nomes têm uma correção por natureza (tese defendida por Crátilo!); 2) a anuência quanto à idéia de que a atividade de nomear não se estende a todos (Crátilo 391b), estando restrita a alguns. E quando Hermógenes aceita investigar com Sócrates a verdadeira adequação dos nomes, este ironiza dizendo que somente os sofistas, mediante pagamento, poderiam atendê-lo, de forma que, à falta de tal quantia, restaria o recurso aos poetas, iniciando por Homero, mas aludindo também a Hesíodo, entre outros. É então que têm início as divertidas etimologias forjadas por Platão. Por meio do método de perguntas e respostas, Sócrates - que encarna o papel do filósofo/dialético -, acaba por subverter os sentidos comumente atribuídos aos nomes, admitindo a supressão ou o acréscimo de letras e sílabas, a fim de obter o sentido filosófico almejado. Cumpre notar que a escolha de cada nome a ter sua etimologia investigada está longe de ser aleatória e reúne precisamente os termos que estão em jogo não só no interior do diálogo, como no pensamento de Platão como um todo (Levin, 2001). 
Desse modo, são examinados nomes de heróis, como o de Heitor e de seu filho (Astíanax), tal que o mesmo significado presente no nome do pai (aquele que detém) seja mantido (Crátilo 393a-b) no nome do filho. Além de Sócrates retirar daí a tese de que o importante no nome é o seu poder (dýnamis) de guardar a entidade forte da coisa nomeada (Crátilo 393d), essa etimologia parece uma resposta à alusão de Crátilo, no início do diálogo (Crátilo 383b), quanto à impossibilidade de Hermógenes ter esse nome, uma vez que o mesmo não seria o filho de Hermes. Mais adiante, ao examinar o nome do deus Hermes (Crátilo 408a-d), atribui-se ao mesmo o significado de "aquele que preside os discursos". Nesse momento, Hermógenes acaba por admitir que Crátilo estaria certo, pois ele mesmo não poderia ser filho de alguém com tais características, dada a refutação do argumento convencionalista que defendera inicialmente. Todavia, logo em seguida, Sócrates examina o nome do filho de Hermes, o deus Pã. Este, como filho, também remeteria aos discursos, uma vez que o discurso significa "todas as coisas" (To pan). Assim, do mesmo modo que Pã, a cuja forma híbrida - metade homem, metade bode - é atribuída uma parte lisa e verdadeira e outra rugosa e falsa, haveria não somente discursos verdadeiros e falsos, como também discursos analogamente híbridos, contendo uma parte verdadeira e outra falsa (Crátilo 408c). Com essa fabulação etimológica, tanto a origem do nome de Hermógenes parece reabilitada, quanto seu discurso convencionalista; ou melhor, a parte verdadeira dele, pois, ao final do diálogo, tem-se a surpreendente concordância de Crátilo e Sócrates quanto à certa importância que a convenção desempenha na correção dos nomes (Crátilo 434e; 435b).

Além desses, são também examinados nomes como "Hades" e "Apolo" que, segundo a etimologia sugerida por Sócrates, têm seus sentidos invertidos, de modo que o primeiro não remeteria ao invisível (Tò aeidés - Crátilo 403b), mas ao desejo maior de todo homem que é vir a ser um homem melhor, o que seria alcançado depois da morte, quando a alma finalmente se separaria do corpo (Crátilo 403d). Hades é então comparado ao filósofo, pois que prenderia, por meio de belos discursos, as almas junto a si, atraídas por seu desejo de virtude. Quanto a Apolo, comumente associado à destruição (do verbo appolimúo, destruir - 404d-e), passa a ser pensado como aquele que purifica, lava e liberta (ho apolouôn te kai apoluôn - 405c).

É justamente pela alusão a esses dois deuses que Dixsaut (2003) propõe um nexo entre o Crátilo e o Fédon, mostrando que neste último, além de os festejos em honra de Apolo serem os responsáveis pelo retardamento da morte de Sócrates, o próprio sentido da morte é invertido, passando a não ser temido, 
mas almejado pelo filósofo que, nessa perspectiva, torna-se o próprio morto, uma vez que morrer adquire o sentido de viver junto ao que é verdadeiro.

Os termos "alma" (psykhé) e "corpo" (sôma), de fundamental importância no âmbito do Fédon e de outros diálogos platônicos, são também examinados no Crátilo. À alma é inicialmente atribuído o sentido de "aquilo que refrigera (anapsykhô) o corpo" (399e). Logo em seguida, Sócrates substitui esse primeiro sentido, chegando a desprezá-lo, e confere-lhe o sentido de "natureza do corpo, que vive e circula" (Ti soi dokei ekhein te kai okhein-400a). Vê-se aí que a própria noção de natureza (phýsis), em Platão, adquire o sentido de princípio, elemento primordial, essência.

O corpo (sôma) é associado ao termo sema, que significa prisão, mas também sinal (Crátilo 400c). Nesse sentido, ao mesmo tempo em que o corpo é pensado como prisão da alma, pode também constituir, ao exemplo do caso de um belo corpo - temática recorrente tanto no Fedro (250c -251b) quanto no Banquete $(210 \mathrm{a}-211 \mathrm{c})$-, o sinal da existência de uma bela alma e, pelo caminho ascendente da dialética, do próprio Belo em si.

Além da análise dos nomes de outros tantos deuses, todos com etimologias bastante pertinentes às temáticas valorizadas por Platão, termos como os elementos da phýsis (água, terra, fogo e ar) são também investigados, sendo alguns de seus sentidos invertidos na direção do pensamento platônico. $\mathrm{Ou}$ seja, recebem uma conotação que os distancia daquela proposta pelos filósofos da phýsis chegando a reabilitar, de certo modo, a tradição poética. Ao termo “Terra”, por exemplo, é atribuído o significado de procriadora (Crátilo 410c), momento em que há uma explícita alusão a Homero.

Cumpre notar que termos como "razoabilidade" (phrónesis), "conhecimento" (epistêmê), "pensamento" (noûs), "intelecção" (noêsis), "sabedoria" (sophía), verdade (alétheia) e falsidade (pseudós) (Crátilo 411c - 412b), entre tantos outros de crucial importância para a filosofia platônica, são inicialmente associados à mobilidade e ao fluxo, o que iria a favor da tese de Crátilo, mas não daquela preferida por Sócrates, segundo a qual todas essas coisas deveriam relacionar-se às essências imutáveis. No entanto, Sócrates logo se encarrega de mostrar que a tese de Crátilo não se sustenta, uma vez que tanto nomes semelhantes quanto dessemelhantes à coisa imitada podem significá-la. Mais que isso, leva Crátilo a recorrer ao costume como critério para a correção de um nome, reabilitando parte do argumento convencionalista de Hermógenes, seu adversário na discussão. Desse modo, torna-se necessário admitir que a convenção, apesar de parecer-lhes (a Crátilo e a Sócrates) um recurso grosseiro (Crátilo 435c), também desempenha importante papel na correção dos nomes. 
É digno de nota que a tese adotada por Sócrates - de que o nome imita a essência imutável das coisas - foi por alguns comentadores (Goldschmidt, 1982, p. 57 et seq.) identificada ao pensamento do próprio Platão, sendo cunhada com o nome de "teoria da linguagem ideal". No diálogo, todavia, Sócrates chega a admitir que Hermógenes (Crátilo 414c) tinha razão ao tê-la considerado um tanto forçosa (Crátilo 435c), embora continue acreditando que essa concepção seria a mais indicada para servir de parâmetro para a justeza dos nomes. Em seguida, Sócrates pergunta a Crátilo sobre o poder que têm os nomes, em face de todos os problemas que eles apresentam. É então que conclui ser melhor buscar o conhecimento das coisas por meio das coisas mesmas e não por meio dos nomes, o que acaba pondo em xeque o papel da linguagem e, no limite, da própria filosofia.

Ora, se por um lado Platão conduz o diálogo nessa direção, por outro, fornece algumas saídas para essas aporias justamente naquilo que ele tratara de demonstrar ao longo de sua incursão pela etimologia, a saber, a possibilidade de retirar da ambigüidade mesma de sentidos contida nos nomes aquele sentido que possa favorecer a sua filosofia. Lembremos que um dos últimos termos que Sócrates toma para análise é justamente o termo "conhecimento" (epistêmê), aquilo que se supunha ser tarefa da filosofia viabilizar pela linguagem. Mediante a análise, tem-se que, ao invés de ser o movimento da alma que acompanha o movimento das coisas, o conhecimento consiste naquilo que fixa (histêsin) a nossa alma nas coisas (Crátilo 437a). Logo em seguida, acrescenta que o sentido de "relato", (historia) e, por conseguinte, algo que compete ao lógos, é o de fixar o fluxo (histêsi ton rhoun - 437b). Conhecer, portanto, significaria apreender, pelo relato, a natureza das coisas, entendendo natureza como princípio, essência. Desse modo, o conhecimento é o acesso àquilo que permanece como é. Contrariamente ao que parecem apontar as aporias no final do Crátilo, tem-se, a partir do próprio diálogo, sobretudo no exame das etimologias, elementos para se pensar que o acesso ao conhecimento só pode se dar pelo lógos, portanto, pela linguagem.

Pensados como elementos das frases, os nomes têm o poder de ensinar e separar - função última da dialética, que coincide com a filosofia. E se o conhecimento é aquilo que fixa nossa alma nas coisas, tem-se que somente pela linguagem é que essa fixação - entendida como o reencontro ou o lembrar-se das formas que um dia contemplou - se torna possível (temática do Fédon). E esse processo de reminiscência não se dá senão no contexto de uma relação de aprendizagem entre mestre e discípulo, relação esta que se realiza eminentemente no âmbito da linguagem. 
O que nos parece particularmente genial no estilo adotado por Platão é que toda essa dimensão lingüística do conhecimento e, portanto, da filosofia, é veiculada no Crátilo num contexto em que a própria natureza dos nomes é aparentemente desautorizada em sua tarefa de dizer a essência das coisas. A nosso ver, essa espécie de ambigüidade contida no tratamento concedido à temática central do diálogo - a justeza dos nomes - pode igualmente ser pensada como uma ilustração performática da própria ambigüidade aludida no diálogo acerca do significado dos nomes e, conseqüentemente, da linguagem.

Com efeito, toda a seção dedicada às etimologias trata de mostrar que os nomes podem assumir significações antagônicas, mesmo aqueles cuja conotação pareceria inequívoca. O termo "ignorância" (amathía), por exemplo, comumente vinculado à falta de conhecimento e, por conseguinte, a uma forma de enfermidade da alma, adquire a possibilidade de significar "a marcha daquele que se move juntamente com deus" (hama theôi iontos -435c). Dessa maneira, acaba aproximando-se de uma das características do filósofo, pensado como aquele que sabe de sua própria ignorância e que, tal como consta no mito da parelha alada do Fedro (246a - 248a), acompanha o séquito do deus em torno das verdades eternas.

A seqüência do diálogo parece levar-nos a associar essa possibilidade de significados antitéticos dos termos à inversão da tese fluxista de Crátilo:

E assim, aqueles nomes que consideramos serem das piores coisas parecer-nos-ão
semelhantes aos nomes das melhores coisas. E penso que, se alguém se empenhasse
nisso, descobriria muitos outros nomes a partir dos quais chegaria à idéia contrária, de
que aquele que estabeleceu os nomes queria significar que as coisas não se moviam
nem estavam em movimento, mas permaneciam. (Crátilo $435 \mathrm{c}-\mathrm{d}$ )

Entretanto, conforme mostra o desenrolar da discussão travada entre Sócrates e Crátilo, seguir esse curso de argumentação não nos conduz à tese de que seja possível ter acesso às essências pelos nomes; antes, leva-nos à constatação de uma precariedade inerente aos mesmos e, por conseguinte, à linguagem em geral, em seu papel de ferramenta a ser utilizada para o conhecimento. Com efeito, faz-nos deparar com aquela série de aporias já mencionadas, seja relativa à impossibilidade de criar nomes a partir de outros elementos que não os próprios nomes, seja à inescrutabilidade dos protoelementos. Como vimos, este parece ser o destino das teses de Hermógenes, Crátilo e também da de Sócrates, uma vez que todas elas, apesar de uma diametral diferença, apostam em uma única natureza concernente à linguagem: ou é pura convenção, ou fluxo incessante ou permanência imutável. Assim, o próprio Platão teria falhado em seu propósito de estabelecer uma vinculação 
entre linguagem e conhecimento, caso levasse às últimas conseqüências a defesa deste apenas pelo acesso às coisas mesmas. Ora, esse acesso não parece autorizado à condição humana, pois a falha identificada na linguagem enquanto tal seria uma espécie de corolário de uma precariedade concernente à própria alma, tema este mais exaustivamente abordado em diálogos como a República (IV, 439d et seq.) e o Fedro (142a et seq.).

A partir da chave interpretativa proposta por Trabattoni (1996), para quem Platão preserva sua concepção metafísica acerca das idéias e da alma, ${ }^{3}$ mas propõe ao mesmo tempo um modo de filosofar intrinsecamente atravessado pela precariedade da alma humana, nossa aposta é a de que Platão deixa emergir sua própria concepção de linguagem a partir do plano dramático do diálogo. Este, por sua vez, outra coisa não mostra senão que a natureza da linguagem é ambígua, cabendo ao filósofo, no papel do dialético, ajuizar sobre o melhor significado a atribuir a um nome dentro de um determinado contexto. Se os nomes - e por conseguinte a linguagem - são ferramentas para ensinar e discriminar as coisas; em outras palavras, se são ferramentas para o conhecimento, sua atividade eminentemente pedagógica se viabiliza na relação mestre-discípulo. É justamente aí que entra em cena a dimensão persuasiva e, conseqüentemente, pragmática da linguagem e também da filosofia platônica. Persuasão esta que é demandada pela alma humana tal como se constitui, a saber, por uma porção maior apetitiva e passional e uma porção menor de cunho racional. Conforme apontam vários de seus diálogos, o trabalho do mestre/filósofo consiste em persuadir a alma do aprendiz/discípulo na direção do conhecimento através de belos discursos e exercícios dialógicos de perguntas e respostas (Cármides, 176b; Sofista, 229d-230d; Leis, II, 664b et seq.). Dado que esse trabalho de psicagogia (Fedro 271e), que coincide com uma verdadeira terapia pela palavra (Entralgo, 1987), deve levar em conta a especificidade de cada alma a ser persuadida (ou purificada), tal que para cada alma deve haver um discurso que melhor lhe convenha, não pode haver conhecimento sem a intervenção da linguagem. Conseqüentemente, não pode haver linguagem sem a possibilidade da polissemia.

Nessa perspectiva, portanto, supomos, à guisa de conclusão, que a estratégia utilizada por Platão de apresentar uma discussão sobre a justeza dos nomes em meio a um cenário aporético aponta para uma crítica à filosofia do tipo doutrinária em prol de uma filosofia mais próxima de uma atividade propriamente dita e, portanto, de uma pragmática.

3 Ver também, Santos (2001), acerca da tese do parentesco das idéias e da alma em Platão. 


\section{Referências}

ANNAS, J. Knowledge and language: the Theaetetus and Cratylus. In: SCHOFIELD, M.; NUSSBAUM, M. (Ed.). Knowledge and Logos: studies in Ancient Greek Philosophy. Cambridge: Cambridge University Press, 2006. p. 95-114.

BARNEY, R. Names and nature in Plato's Cratyllus. N. York and London: Routledge, 2001, $227 \mathrm{p}$.

DIXAUT, M. La Natura Filosofica: Saggio sui dialoghi di Platone. Napoli: Lofredo Editore, 2003.

ENTRALGO, P. La curación por la palabra em la Antigüedad Clásica. Barcelona: Anthropos, 1997.

GAUDIN, C. Le devenir-signe des noms dans le Cratyle. kairos kai logos. Cahiers du Centre d'Études sur la Pensee Antique. Aix-en-Provence, n. 5, p. 1-20, 1996.

GOLDSCHMIDT, V. Essai sur le "Cratyle”. Paris: Vrin, 1982.

HÖSLE, V. G. 'Interpreting Philosophical dialogues'. In: HARMS, W. et al. Antique und Abendland. Band XLVIII. Berlin / New York: Walter de Gruyter, 2002. p. 68-90. LEVIN, S. The ancient quarrel between Philosophy and poetry revisited: Plato and the greek literary tradition. Oxford: Oxford University Press, 2001.

PLATÃO. Crátilo. Lisboa: Instituto Piaget, 2001.

PLATÃO. Diálogos: Teeteto e Crátilo. Trad. C. A. Nunes. Belém: Editora da UFPA, 1988.

PLATÃO. O Banquete. Rio de Janeiro: BCD União de Editoras, 2001.

PLATÃO. Fedro. Lisboa: Guimarães Editores, 1989.

PLATO. Cratylus. In: COOPER, J. M.; HUTCHINSON, D. S. Plato Complete Works. Indianapolis / Cambridge: Hackett Publishing Company, 1997.

PLATO. Sophist. In: COOPER, J. M.; HUTCHINSON, D. S. Plato Complete Works. Indianapolis / Cambridge: Hackett Publishing Company, 1997.

PLATO. Charmides. In: COOPER, J. M.; HUTCHINSON, D. S. Plato Complete Works. Indianapolis / Cambridge: Hackett Publishing Company, 1997.

PLATO. Phaedrus. In: COOPER, J. M.; HUTCHINSON, D. S. Plato Complete Works. Indianapolis / Cambridge: Hackett Publishing Company, 1997.

PLATON. Cratyle. Paris: GF-Flamarion, 1998.

PLATONE. Opere complete, con il testo greco, itinerari di navigazione di Gabriele Giannantoni; a cura di Giuseppe Iannotta, Alberto Manchi, Daniela Papitto. RomaBari: Laterza, 1999.

PLATONE. Fedro. Milano: Edizioni Bruno Mondadori, 1996.

SEDLEY, D. Plato's Cratylus. Cambridge: Cambridge University Press, 2003.

SANTOS, J. G. T. Introdução. In: PLATÃO. Crátilo. Lisboa: Inst. Piaget, 2001. p. 9-42.

TRABATTONI, F. Scrivere nell'anima: verità, dialettica e persuasione in Platone. Firenze: La nuova Itália Editrice, 1994. 